\title{
INFLUENCE OF THE HUMIFICATION PROCESS ON THE PROPERTIES OF PEAT HUMIC ACIDS
}

\author{
Jānis Šīre and Māris Kḷaviṇš \\ Faculty of Geographical and Earth Sciences, University of Latvia, Raina bulv. 19, Rīga, LV-1586, LATVIA
}

Contributed by Māris Kḷaviṇš

\begin{abstract}
Comparative and complex characterisation of peat humic acids (HAs) isolated from peat profiles of different origin in Latvia was conducted. Elemental and functional analysis of the isolated HAs was made and their acidity and molecular weight were estimated. Spectral characterisation included UV-Vis, IR, electron spin resonance and fluorescence spectra. Structural characterisation of $\mathrm{HAs}$ was by both ${ }^{1} \mathrm{H}$ and ${ }^{13} \mathrm{C}$ nuclear magnetic resonance spectra. Properties of $\mathrm{HAs}$ isolated from the Latvian peat were compared with HA from other sources (soil, water, coal and synthetic humic substances). Major properties of peat HAs depended on their origin, indicating the importance of humification processes. HAs isolated from peat of more recent origin were more similar to soil Has, while there was a greater degree of humification in part from older sources.
\end{abstract}

Key words: humic acid, peat, Latvia, humification degree.

\section{INTRODUCTION}

Humic substances (HSs) are the dominant naturally occurring organic substances (Falkowski et al., 2000). HSs are a general category of naturally occurring, biogenic, heterogeneous organic substances that can be generally characterised as yellow to black in colour, of high molecular weight, and refractory (Stevenson, 1994). They consist of several groups of substances that depending on their solubility can be grouped as follows: humin is the HS fraction that is insoluble in water at any $\mathrm{pH}$; humic acid (HA) is the fraction insoluble in water under acidic conditions $(\mathrm{pH}<2)$, but is soluble at greater $\mathrm{pH}$; and fulvic acid is the fraction soluble in water at all pHs (Tan, 2003). HSs form most of the organic component of soil, peat and natural waters, they influence the process of formation of fossil fuels, and play a major role in the global carbon (C) geochemical cycle (Falkowski et al., 2000). Significant reserves of organic C are stored in wetland soils and as peat; as much as $60-85 \%$ of the organic matter in peat is HSs (Garnier-Sillam et al., 1999). Peat is a dark-colored and mostly organic material (mineral matter usually $<25 \%$ ) formed in water-saturated, anaerobic wetland environments from decomposition of mosses, sedges, grasses, reeds, shrubs and trees (Zaccone et al., 2007).

The study of peat HSs, especially their profiles is important due to their industrial significance. Peat can be a source of up to $500 \mathrm{Gt}$ of $\mathrm{C}$ as HAs of industrial value (Markov et al., 1998). However, there have been few studies aimed at understanding of $\mathrm{C}$ biogeochemical cycling, and structure and properties of peat HSs, despite the high potential for industrial production (Hänninen et al., 1993; Lu et al., 2000;
Francioso et al., 2003; Li et al., 2003; Gondar et al., 2005; Fong and Murtedza, 2007).

The aim of the present paper is to determine the properties of peat HAs isolated from peat profiles and to evaluate the impact of the character of humification processes.

\section{MATERIALS AND METHODS}

Peat sampling. Twenty-eight peat samples were collected from profiles of five raised bogs of industrial importance in Latvia. The sampling strategy was developed to study properties of peat mass of industrial importance. Profiles were obtained, after removal of top layers consisting of bog plants and undecomposed peat (acrotelm), at the depth of 0-145 cm (catotelm). The "zero" horizon, representing peat horizons of industrial importance, was aged at 400-1400 y by ${ }^{14} \mathrm{C}$ dating. Peat samples were dried at $105^{\circ} \mathrm{C}$, and then homogenised and sieved through a $1-\mathrm{mm}$ sieve.

Characterisation of peat. The analysis of botanical composition was performed microscopically, using a Carl-Zeiss binocular microscope, and decomposition degree was determined (Lishtvan and Korol, 1975). The ${ }^{14} \mathrm{C}$ dating of the peat samples was made at the Institute of Geology of the Tallinn Technical University (Estonia). Basic characteristics of the peat samples are displayed in Table 1 .

Materials. Analytical quality reagents (from Merck Co, Sigma-Aldrich Co, and Fluka Chemie AG RdH Laborchemikalien $\mathrm{GmbH} \mathrm{Co}$ ) were used without further purification. 
BASIC CHARACTERISTICS OF THE PEAT SAMPLES

\begin{tabular}{|c|c|c|}
\hline Sample & Depth $(\mathrm{cm})$ & Peat type \\
\hline Ploce 0-30 & $0-30$ & High-type fuscum peat \\
\hline Ploce $30-60$ & $31-60$ & High-type fuscum peat \\
\hline Ploce 60-85 & $61-85$ & High-type fuscum peat \\
\hline Ploce $85-110$ & $86-110$ & High-type fuscum peat \\
\hline Ploce $110-130$ & $111-130$ & $\begin{array}{l}\text { High-type cotton-grass- } \\
\text { sphagnum peat }\end{array}$ \\
\hline Gāgu 0-20 & $0-20$ & $\begin{array}{l}\text { High-type cotton-grass- } \\
\text { sphagnum peat }\end{array}$ \\
\hline Gāgu 20-40 & $21-40$ & $\begin{array}{l}\text { High-type cotton-grass- } \\
\text { sphagnum peat }\end{array}$ \\
\hline Gāgu 40-60 & $41-60$ & $\begin{array}{l}\text { High-type cotton-grass- } \\
\text { sphagnum peat }\end{array}$ \\
\hline Gāgu 60-80 & $61-80$ & High-type fuscum peat \\
\hline Gāgu 80-100 & $81-100$ & High-type fuscum peat \\
\hline Gāgu 100-120 & $101-120$ & High-type fuscum peat \\
\hline Gāgu 120-140 & $121-140$ & High-type fuscum peat \\
\hline Kaigu 0-25 & $0-25$ & $\begin{array}{l}\text { High-type cotton-grass- } \\
\text { sphagnum peat }\end{array}$ \\
\hline Kaigu 25-45 & $26-45$ & High-type fuscum peat \\
\hline Kaigu 45-70 & $46-70$ & High-type fuscum peat \\
\hline Kaigu 70-95 & $71-95$ & $\begin{array}{c}\text { High-type narrow-leaf sphag- } \\
\text { num peat }\end{array}$ \\
\hline Kaigu 95-125 & $96-125$ & $\begin{array}{c}\text { High-type narrow-leaf sphag- } \\
\text { num peat }\end{array}$ \\
\hline Kaigu 125-145 & $126-145$ & High-type fuscum peat \\
\hline Dižais Veiķenieks 0-25 & $0-25$ & High-type fuscum peat \\
\hline Dižais Veiḳenieks 25-52 & $26-52$ & High-type fuscum peat \\
\hline Dižais Veik̦enieks 52-75 & $53-75$ & High-type fuscum peat \\
\hline Dižais Veiķenieks 75-98 & 76-98 & High-type fuscum peat \\
\hline Dižais Veiķenieks 98-118 & 99-118 & High-type fuscum peat \\
\hline Mazais Veiķenieks 0-30 & $0-30$ & High-type fuscum peat \\
\hline Mazais Veikenieks 30-60 & $31-60$ & $\begin{array}{l}\text { High-type Magellan's } \\
\text { sphagnum peat }\end{array}$ \\
\hline Mazais Veiķenieks 60-90 & $61-90$ & $\begin{array}{c}\text { Transition-type tree-grass } \\
\text { peat }\end{array}$ \\
\hline Mazais Veiķenieks 90-125 & $91-125$ & Low-type tree-grass peat \\
\hline
\end{tabular}

Isolation of HAs. HAs were extracted and purified using procedures recommended by the International Humic Substances Society (IHSS) (Tan, 2005). Industrially-produced HA (Aldrich) and IHSS reference HA isolated from $\mathrm{Pa}-$ hokee (USA) peat were used for comparison.

Characterisation of HAs. Elemental analysis (C, H, N, S and O) was carried out using an Elemental Analyser Model EA-1108 (Carlo Erba Instruments) and the found values were normalised in respect to ash content. Ash content was measured after heating of $50 \mathrm{mg}$ of each $\mathrm{HA}$ at $750{ }^{\circ} \mathrm{C}$ for $8 \mathrm{~h}$. UV/Vis spectra were recorded on a Thermospectronic Helios ć UV (Thermo electron Co) spectrophotometer in a $1-\mathrm{cm}$ quartz cuvette. The ratio $\mathrm{E}_{4} / \mathrm{E}_{6}$ (Chen et al., 1977), i.e. ratio of absorbances at 465 and $665 \mathrm{~nm}$ was determined for a solution of $5 \mathrm{mg}$ of the HA in $10 \mathrm{ml}$ of 0.05 $\mathrm{N} \mathrm{NaHCO}$.
An automatic titrator TitroLine easy (Schott-Geräte $\mathrm{GmbH}$ ) was used to measure acidity of each HA (Tan, 2003).

High pressure size exclusion chromatography (HPSEC) was used to determine weight-averaged molecular weight $\left(M_{w}\right)$. HPSEC was performed using a Waters 510 solvent pump, a Waters 486 variable wavelength detector, and a Waters Protein-Pak 125 modified silica column. Phosphate buffer $(0.028 \mathrm{M}, \mathrm{pH} 6.8)$ was used as a mobile phase at a flow rate of $1 \mathrm{ml} / \mathrm{min}$. The SEC column was calibrated using polydextrans $(0.83,4.4,9.9,21.4$ and $43.5 \mathrm{kDa})$ and sodium polystyrenesulfonates $(1.37,3.8,6.71,8.0,8.6,13.4$ and $16.9 \mathrm{kDa})$. The standard kits were purchased from the Polymer Standard Service (Mainz, Germany). The calibration curve was expanded into the low MW region by means of mono- and oligosaccharides (180, 342 and 504 Da) and glycerol. Blue dextran (2000 kDa) served as a void volume probe, methanol as a permeation volume probe.

Humification degree. A $1.00 \mathrm{~g}$ sample of peat was shaken for $24 \mathrm{~h}$ with $50 \mathrm{ml}$ of $1.0 \mathrm{M} \mathrm{NaOH}$, filtered, and in the filtrate the total organic $\mathrm{C}$ of the alkaline extract, containing HSs $\left(\mathrm{C}_{\mathrm{HS}}\right)$, was determined $(\mathrm{mg} \mathrm{C} / \mathrm{g}$ ). The peat humification degree $(H D)$ was calculated as:

$H D=\frac{C_{H S}}{C_{\text {peat }}} \times 100$, where $\mathrm{C}$ is carbon in the sample $(\mathrm{mg} / \mathrm{g})$.

\section{RESULTS}

Properties of the studied peat samples. Peat HSs can be considered especially appropriate for studies to understand the $\mathrm{C}$ biogeochemical cycle because links can be made between HS properties and the decomposition degree of the original organic matter. In addition, studies of peat humification are of definite applied and theoretical interest, considering the growing need for industrially-produced HA.

It is well known that major properties of peat down the profile might be explained by presence of the following structural layers (Clymo, 1991):

1. Acrotelm is the largely oxygenated surface layer with high hydraulic conductivity and within which the water table fluctuates. There are two layers within the acrotelm: the euphotic and the aerobic layers. Within the euphotic layer the growth of plants and photosynthesis takes place and this layer has a low dry bulk density, and consists of living plants and their prime decomposition products. The aerobic layer (10-50 cm thickness) is formed at the base of the euphotic layer where most of the plant material is dead and microbial aerobic decay is the major process, supported by presence of oxygen and moisture. Most of the primary production of plant material in this layer is aerobically decomposed and only a minor fraction is accumulated as peat. The peat mass in the aerobic layer is still very porous and has a high hydraulic conductivity and so is of little industrial importance. 
2. Catotelm is the underlying, saturated and mainly anoxic layer with low hydraulic conductivity; within the catotelm, there are the collapse and the lower peat layers.

For peat industrial mining the homogeneous, "bulk" peat mass (the catotelm) is of major importance. For peat extraction, the living and undecomposed plant material is of minor value and is usually removed. The present study investigated the variability of peat HA properties only from the catotelm.

In this study the peat samples were from different depths in five raised bogs in Latvia, representing bogs of industrial importance, and reflecting bog development conditions in Northern Europe. The botanical composition of the deepest peat layer was mostly high-type cotton-grass-sphagnum peat and high-type fuscum peat, but in the upper layer it was high-type fuscum peat (Table 1). The age range of samples was 400-2260 y, and their decomposition varied from 8 to $31 \%$ (H2 and $\mathrm{H} 6$ on von Post scale, respectively; Table 2). The age and decomposition degree of peat gradually increased with increased depth (Table 2).

Elemental composition and functional characteristics of peat humic acids. There was significant variation in elemental composition of HAs within the peat profiles. It is assumed that during the peat extraction process the topmost peat layers are subjected to periodic drying and wetting, which would increase aerobic decomposition and oxidation (Anderson and Hepburn, 1986). As a result, the elemental

Table 2

FUNCTIONAL AND MOLECULAR CHARACTERISTICS OF HAs ISOLATED FROM PEAT SAMPLES

\begin{tabular}{|c|c|c|c|c|}
\hline Sample & $\begin{array}{c}\text { Peat age } \\
\text { (y) }\end{array}$ & $\begin{array}{l}\text { Peat de- } \\
\text { composi- } \\
\text { tion }(\%)\end{array}$ & $\begin{array}{c}\text { Total acid- } \\
\text { ity of HA } \\
\text { (meq/g) }\end{array}$ & $\begin{array}{c}M_{w} \text { of HA } \\
\text { (Da) }\end{array}$ \\
\hline Ploce 0-30 & 460 & 14 & 8.26 & 22000 \\
\hline Ploce $30-60$ & n.d. & 12 & 8.36 & n.d. \\
\hline Ploce 60-85 & 1560 & 14 & 7.68 & 18000 \\
\hline Ploce $85-110$ & n.d. & 14 & 7.51 & n.d. \\
\hline Ploce $110-130$ & 1670 & 16 & 7.43 & 22500 \\
\hline Kaigu 0-25 & 810 & 13 & 7.61 & 30600 \\
\hline Kaigu 25-45 & n.d. & 10 & 7.64 & 32600 \\
\hline Kaigu 45-70 & 1590 & 11 & 7.25 & n.d. \\
\hline Kaigu 70-95 & n.d. & 13 & 7.15 & n.d. \\
\hline Kaigu 95-125 & n.d. & 17 & 7.71 & 18500 \\
\hline Kaigu 125-145 & 2260 & 19 & 7.51 & 21500 \\
\hline Dižais Veiķenieks 0-25 & 520 & 12 & 7.75 & n.d. \\
\hline Dižais Veikenieks 25-52 & n.d. & 12 & 8.25 & 33000 \\
\hline Dižais Veik,enieks 52-75 & 980 & 16 & 6.98 & n.d. \\
\hline Dižais Veiķenieks 75-98 & n.d. & 19 & 7.17 & 32500 \\
\hline Dižais Veiķenieks 98-118 & 1350 & 16 & 6.67 & 26000 \\
\hline Mazais Veiķenieks 0-30 & 400 & 8 & 7.67 & 37000 \\
\hline Mazais Veiķenieks 30-60 & n.d. & 14 & 7.00 & n.d. \\
\hline Mazais Veiķenieks 60-90 & n.d. & 27 & 6.34 & n.d. \\
\hline Mazais Veiķenieks 90-125 & 1180 & 31 & 6.72 & n.d. \\
\hline
\end{tabular}

composition of peat HAs does not regularly change with the depth in the peat column.

Depending on the bog and the intervals of changes, the elemental compositions of the studied peat HAs (Table 3) were highly variable: $\mathrm{C}$ was $49-57 \%$; $\mathrm{H}$ was $4.6-5.7 \%$, $\mathrm{N}$ was $1.6-2.8 \%$, S was $0.5-1.5 \%$ and ash was $0.1-1.2 \%$. The $\mathrm{O}$ content, with range $32-42 \%$, was determined by mass balance. In general, $\mathrm{C}$ and $\mathrm{H}$ concentrations increased with depth. $\mathrm{N}$ concentrations decreased with depth, but S concentration was very variable down the profile. The elemental composition of HAs from peat in Latvia is of similar magnitude to those for peat HAs from other regions of the world (Anderson and Hepburn, 1986; Qiamg et al., 1993; Yamaguchi et al., 1998; Garnier-Sillam et al., 1999; Zaccone et al., 2007).

The main atomic ratios $(\mathrm{H} / \mathrm{C}, \mathrm{N} / \mathrm{C}$ and $\mathrm{O} / \mathrm{C})$ are reported in Table 4 .

The most dominant functional groups in the structure of HAs were carboxyl and phenolic hydroxyl groups, giving a sum of total acidity of HAs (Table 2). The range of total acidity was $6.67-8.36 \mathrm{meq} / \mathrm{g}$ and was usually higher for HAs from upper peat layers.

Table 3

COMPOSITION OF PEAT HAs

\begin{tabular}{|c|c|c|c|c|c|c|}
\hline $\begin{array}{l}\text { Sample and sampling depth } \\
\qquad(\mathrm{cm})\end{array}$ & $\mathrm{C}(\%)$ & $\mathrm{H}(\%)$ & $\mathrm{N}(\%)$ & $\mathrm{S}(\%)$ & $\mathrm{O}(\%)$ & \begin{tabular}{|c} 
Ash \\
content \\
$(\%)$
\end{tabular} \\
\hline Dižais Veiķenieks 0-25 & 54.80 & 5.09 & 2.19 & 0.83 & 36.48 & 0.61 \\
\hline Dižais Veik̦enieks 25-52 & 54.11 & 5.07 & 2.10 & 0.95 & 37.30 & 0.47 \\
\hline Dižais Veiķenieks 52-75 & 54.38 & 5.72 & 2.46 & 0.90 & 35.92 & 0.62 \\
\hline Dižais Veik̦enieks 75-98 & 54.31 & 5.44 & 2.59 & 0.82 & 36.37 & 0.47 \\
\hline Dižais Veiķenieks $98-118$ & 56.36 & 5.59 & 2.23 & 0.66 & 34.99 & 0.18 \\
\hline Gāgu 0-20 & 49.94 & 4.68 & 2.11 & 0.34 & 41.49 & 1.45 \\
\hline Gāgu 20-40 & 54.32 & 5.03 & 2.36 & 0.89 & 36.78 & 0.62 \\
\hline Gāgu 40-60 & 54.87 & 4.93 & 2.10 & 0.55 & 36.93 & 0.62 \\
\hline Gāgu 60-80 & 58.76 & 5.20 & 2.15 & 0.74 & 32.53 & 0.62 \\
\hline Gāgu 80-100 & 57.75 & 4.50 & 1.98 & 0.39 & 35.26 & 0.12 \\
\hline Gāgu 100-120 & 52.09 & 4.94 & 1.66 & 1.27 & 39.42 & 0.62 \\
\hline Gāgu 120-140 & 53.80 & 5.34 & 1.96 & 0.78 & 37.83 & 0.29 \\
\hline Kaigu 0-25 & 57.05 & 5.06 & 2.62 & 0.57 & 34.45 & 0.25 \\
\hline Kaigu 25-45 & 54.52 & 5.42 & 2.52 & 0.85 & 36.39 & 0.30 \\
\hline Kaigu 45-70 & 55.14 & 5.07 & 1.96 & 0.87 & 36.85 & 0.11 \\
\hline Kaigu 70-95 & 57.61 & 5.35 & 2.22 & 0.59 & 33.93 & 0.30 \\
\hline Kaigu 95-125 & 57.60 & 5.19 & 1.82 & 1.59 & 33.50 & 0.30 \\
\hline Kaigu 125-145 & 56.26 & 5.43 & 2.37 & 0.09 & 35.33 & 0.52 \\
\hline Mazais Veikenieks 0-30 & 54.10 & 5.33 & 2.24 & 1.55 & 36.68 & 0.10 \\
\hline Mazais Veiķenieks 30-60 & 57.51 & 5.35 & 2.73 & 0.81 & 32.94 & 0.66 \\
\hline Mazais Veiķenieks 60-90 & 55.36 & 5.29 & 2.56 & 0.80 & 35.33 & 0.66 \\
\hline Mazais Veiķenieks 90-125 & 54.89 & 5.23 & 2.76 & 0.79 & 35.11 & 1.22 \\
\hline Ploce 0-30 & 51.51 & 4.80 & 2.12 & 1.03 & 40.30 & 0.24 \\
\hline Ploce $30-60$ & 51.13 & 4.81 & 2.06 & 0.78 & 40.97 & 0.25 \\
\hline Ploce 60-85 & 51.12 & 4.87 & 2.05 & 0.92 & 40.78 & 0.26 \\
\hline Ploce 85-110 & 52.11 & 4.61 & 1.60 & 0.73 & 40.70 & 0.25 \\
\hline Ploce $110-130$ & 57.50 & 4.94 & 1.92 & 0.78 & 34.61 & 0.26 \\
\hline
\end{tabular}


Table 4

ELEMENTAL RATIOS AND HUMIFICATION INDICATORS OF PEAT HAs

\begin{tabular}{|c|c|c|c|c|c|}
\hline Sample & $\mathrm{E}_{4} / \mathrm{E}_{6}$ & $\mathrm{H} / \mathrm{C}$ & $\mathrm{N} / \mathrm{C}$ & $\mathrm{O} / \mathrm{C}$ & $\begin{array}{c}\text { Humific- } \\
\text { ation } \\
\text { degree } \\
\text { (HD) } \\
\end{array}$ \\
\hline Dižais Veiķenieks 0-25 & 3.65 & 1.11 & 0.03 & 0.50 & 1.014 \\
\hline Dižais Veik̦enieks 25-52 & 3.74 & 1.12 & 0.03 & 0.52 & 0.942 \\
\hline Dižais Veik̦enieks 52-75 & 3.00 & 1.25 & 0.04 & 0.50 & 1.055 \\
\hline Dižais Veiķenieks 75-98 & 2.83 & 1.19 & 0.04 & 0.50 & 0.994 \\
\hline Dižais Veiķenieks 98-118 & 3.38 & 1.18 & 0.03 & 0.47 & 1.102 \\
\hline Gāgu 0-20 & 2.81 & 1.12 & 0.04 & 0.62 & 1.029 \\
\hline Gāgu 20-40 & 3.17 & 1.10 & 0.04 & 0.51 & 1.107 \\
\hline Gāgu 40-60 & 2.88 & 1.07 & 0.03 & 0.51 & 1.124 \\
\hline Gāgu 60-80 & 2.93 & 1.05 & 0.03 & 0.42 & 1.214 \\
\hline Gāgu 80-100 & 3.06 & 0.93 & 0.03 & 0.46 & 1.168 \\
\hline Gāgu 100-120 & 3.27 & 1.13 & 0.03 & 0.57 & 1.048 \\
\hline Gāgu 120-140 & 3.48 & 1.18 & 0.03 & 0.53 & 1.059 \\
\hline Kaigu 0-25 & 2.89 & 1.06 & 0.04 & 0.45 & 1.182 \\
\hline Kaigu 25-45 & 2.84 & 1.18 & 0.04 & 0.50 & 1.106 \\
\hline Kaigu 45-70 & 3.13 & 1.10 & 0.03 & 0.50 & 1.113 \\
\hline Kaigu 70-95 & 2.73 & 1.11 & 0.03 & 0.44 & 1.187 \\
\hline Kaigu 95-125 & 3.00 & 1.07 & 0.03 & 0.44 & 1.187 \\
\hline Kaigu 125-145 & 3.70 & 1.15 & 0.04 & 0.47 & 1.348 \\
\hline Mazais Veiķenieks 0-30 & 2.67 & 1.17 & 0.04 & 0.51 & 1.170 \\
\hline Mazais Veiķenieks 30-60 & 2.50 & 1.11 & 0.04 & 0.43 & 1.123 \\
\hline Mazais Veiķenieks 60-90 & 3.67 & 1.14 & 0.04 & 0.48 & 1.144 \\
\hline Mazais Veiķenieks 90-125 & 3.73 & 1.14 & 0.04 & 0.48 & 1.157 \\
\hline Ploce $0-30$ & 3.70 & 1.11 & 0.04 & 0.59 & 1.206 \\
\hline Ploce $30-60$ & 3.60 & 1.12 & 0.03 & 0.60 & 1.184 \\
\hline Ploce 60-85 & 3.00 & 1.14 & 0.03 & 0.60 & 1.237 \\
\hline Ploce $85-110$ & 3.00 & 1.05 & 0.03 & 0.59 & 1.055 \\
\hline Ploce $110-130$ & 3.76 & 1.02 & 0.03 & 0.45 & 1.035 \\
\hline
\end{tabular}

The molecular weight (Table 2) of peat HA was characterized by $M_{w}$. The found molecular masses of HAs were all comparatively high, up to $37000 \mathrm{Da}$.

\section{DISCUSSION}

Relation of peat humic acid properties to peat decomposition (humification) degree. The peat HAs were analysed using van Krevelen graphs as frequently applied for studies of HSs and the $\mathrm{C}$ biogeochemical cycle (Van Krevelen, 1950). Table 4 shows the elemental ratios of the studied peat HA samples. According to Orlov (1990), the index of atomic ratios $\mathrm{O} / \mathrm{C}, \mathrm{H} / \mathrm{C}$ and $\mathrm{N} / \mathrm{C}$ is useful in identification of structural changes and the degree of maturity of HSs obtained from different environments. The relation between $\mathrm{H} / \mathrm{C}$ atomic ratio and $\mathrm{O} / \mathrm{C}$ atomic ratio of $\mathrm{HAs}$ of differing decomposition degree, beginning with bog plants up to brown coal, lignite and coal - reveals changes in the associated elemental composition (Fig. 1). Figure 1 can be considered a graphical representation of the humification process, indicating the degree of maturity and intensity of degradation processes such as dehydrogenation (reduction of $\mathrm{H} / \mathrm{C}$ ratio), decarboxylation (reduction of $\mathrm{O} / \mathrm{C}$ ratio), demethylation occurring during the decay of peat-forming plants, and peat humus maturation continuing up to coal. These changes are especially evident if atomic ratios of peat-forming plants (Sector 3 in Fig. 1) are compared to the atomic ratio of organic matter of a high decomposition degree (low moor peat, coal) (Sector 3 in Fig. 1). From the point of view of chemistry, peat HAs have an intermediate position (Sector 5 in Fig. 1) between the living organic matter and coal organic matter and their structure is formed in a process in which more labile structures (carbohydrates, amino acids, etc) are destroyed, but thermodynamically more stable aromatic and polyaromatic structures emerge. Comparatively, the studied peat HAs are at the start of the transformation process of living organic matter.

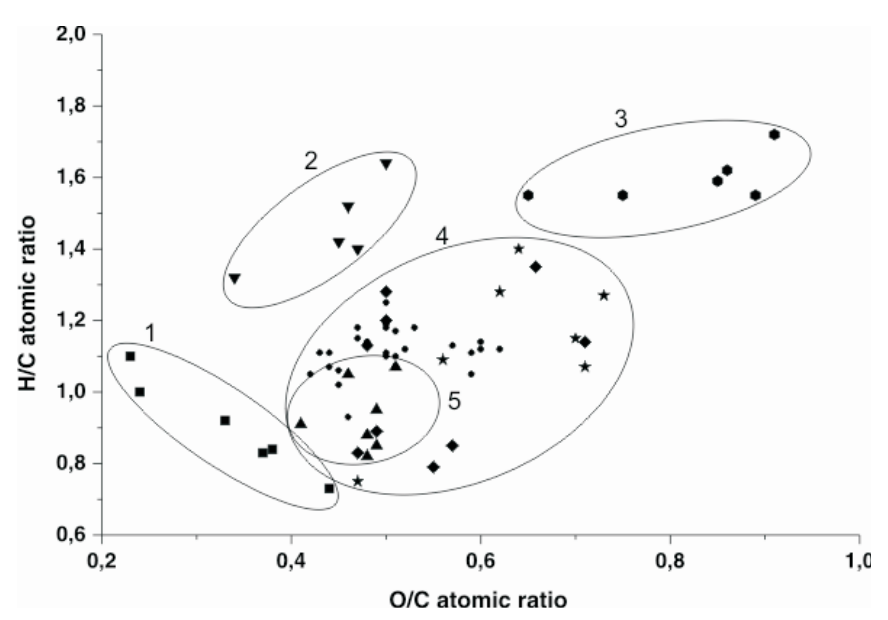

Fig. 1. Van Krevelen (H/C vs. O/C atomic ratio) graph of bog plants (O); HAs isolated from peat samples from bogs in Latvia $(\mathbf{O})$; reference peat HA (IHSS 2008) and peat HA ( $\star$ ) (Belyaeva, 2004); soil HA $(\diamond)$; HA from different coals and lignite ( $\mathbf{\square}$ (Krechetova, 1994; Dick et al., 2002; Belyaeva, 2004), sedimentary HA ( $)$ (Senesi and Sakellariadou 1994) and aquatic HA (p) (Reckhow et al., 1990; Pettersson et al., 1994; Artinger et al., 2000).

To provide reliable and quantitative information about the diagenesis of HAs, we carried out further studies of the dependence of the elemental composition of the peat samples on their age (depth and decomposition degree) (Fig. 2). The trends of dependence between $\mathrm{H} / \mathrm{C}$ values and the depth of the peat samples were mostly negatively related, demonstrating that dehydrogenation is amongst the dominant processes during ageing of peat HAs.

$\mathrm{O} / \mathrm{C}$ vs. N/C atomic ratios indicate that the decarboxylation processes were in line with the reduction of $\mathrm{N}$ concentration relative to $\mathrm{C}$ content in HSs (Fig. 3).

Studies of elemental composition of peat HAs extracted from a peat column can give information about ongoing humification reactions during peat development. Humification has been mostly studied with the aim to analyse composting and soil formation processes. However, the humification process in peat is much different from that in composts and soils, which have a quite rapid decomposition 


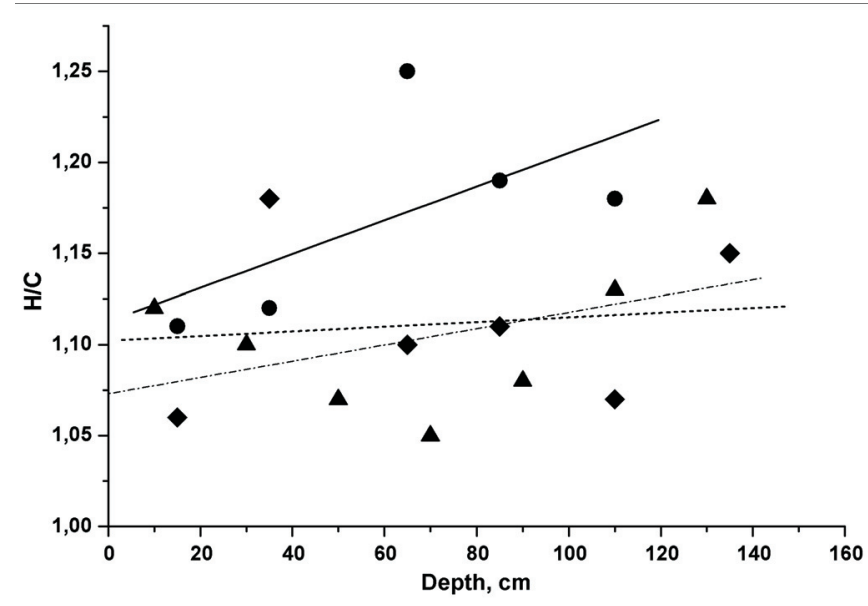

Fig. 2. Dependence of $\mathrm{H} / \mathrm{C}$ values of peat HAs on peat column depth in different peat bogs. - Dižais Veikenieks peat bog $\left(\longrightarrow \quad \mathrm{Y}=1.11261+9.25606^{-4} \cdot \mathrm{X} ;\right.$
$\mathrm{R}=0.61719 ; \mathrm{P}=0.26739)$
$\begin{array}{ll}\text { A Gāgu peat bog }(-\cdots-\cdot & \mathrm{Y}=1.07304+4.46429^{-4} \cdot \mathrm{X} ; \mathrm{R}=0.44305 ; \\ \mathrm{P}=0.31945) & \\ \text { Kaigu peat bog }(\cdots \cdots \cdots . . & \mathrm{Y}=1.10217+1.28007^{-4} \cdot \mathrm{X} ; \mathrm{R}=0.12521 ; \\ \mathrm{P}=0.81317)\end{array}$

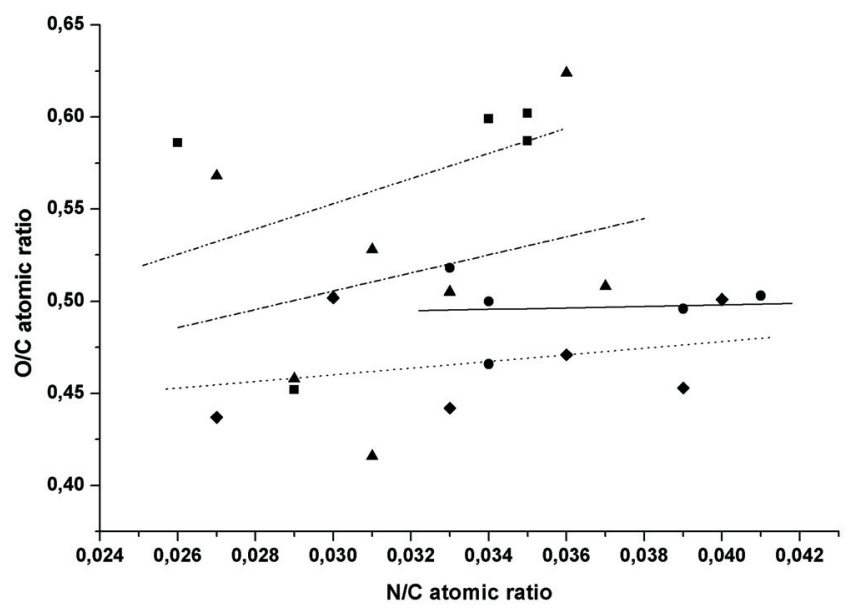

Fig. 3. Van Krevelen graph of $\mathrm{O} / \mathrm{C}$ and N/C atomic ratios in different peat bogs.

- Dižais Veiķenieks peat bog $(\longrightarrow \mathrm{Y}=0.48206+0.40157 \cdot \mathrm{X} ; \mathrm{R}=$ $0.07524 ; \mathrm{P}=0.9043$ )

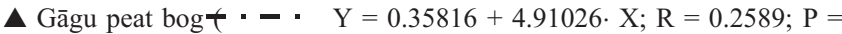
$0.57506)$

Kaigu peat bog $(\cdots \cdots \cdots . . . \mathrm{Y}=0.40595+1.80637 \cdot \mathrm{X} ; \mathrm{R}=0.32208 ; \mathrm{P}=$ $0.53359)$

Ploce peat bog $(-\cdots Y=0.34707+6.85928 \cdot X ; \mathrm{R}=0.44021 ; \mathrm{P}=$ $0.45818)$

of organic matter in early humification stages. However, in waterlogged environments, under the impact of anaerobic and acidic conditions, the humification process of the saturated peat layers is very much retarded. Nevertheless, in peat it is possible to follow the humification process for very long periods (more than several thousand years). The results demonstrate that it is possible to study the stage of humification of organic matter in peat according to its age and apply the methods of analysis to the estimation of peat humification. HD is suggested as a good measure of peat decomposition.

As the present study shows, this parameter corresponds well to the peat decomposition degree and age, and so can be used to study the transformation processes of organic matter (Fig. 4).

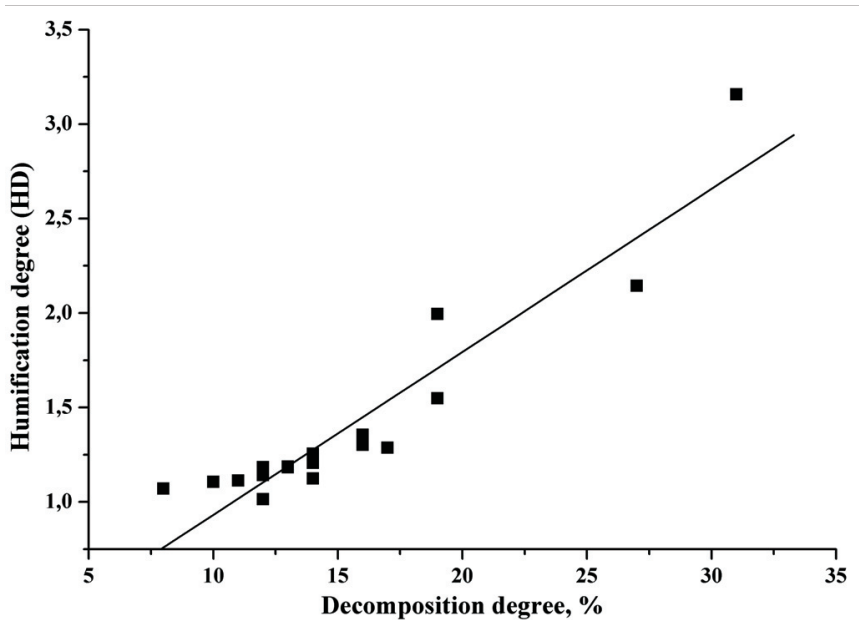

$\mathrm{Y}=0.06791+0.08631 \cdot \mathrm{X} ; \mathrm{R}=0.93248 ; \mathrm{P}=<0.0001$

Fig. 4. Correlation between the humification degree of the peat samples and peat decomposition in Dižais Veiķenieks, Gāgu and Kaigu peat bogs.

The widely used humification indicator, $\mathrm{E}_{4} / \mathrm{E}_{6}$ ratio, does not give very much information about the character of humification processes of HAs within peat columns, since it is better correlated with the molecular size of HSs, rather than their chemical structure (Fig. 4) as suggested by Chen et al. (1977) for soil HSs.

$\mathrm{UV}-\mathrm{V}$ is absorption ratios were measured to provide information about the humification state of peat samples. The ratio $\mathrm{E}_{4} / \mathrm{E}_{6}$ is often used to describe the extent of condensation of the aromatic C-containing structures; low ratios reflect high degrees of condensation of aromatics, while high ratios mean the presence of large quantities of aliphatic structures and low amounts of condensed aromatics (Chin et al., 1997). This ratio is also inversely related to the degree of aromaticity, particle size, molecular weight and acidity (Uyguner et al., 2004).

In the present study, the variability of the $\mathrm{E}_{4} / \mathrm{E}_{6}$ ratios in the peat profiles was generally low (Table 4). The correlations between different chemical parameters were investigated and the plot of the total acidity values and the $\mathrm{E}_{4} / \mathrm{E}_{6}$ ratios showed strong negative correlations in peat bog profiles (Fig. 6). Increases of the acidic groups in the HA samples resulted in a reduced $\mathrm{E}_{4} / \mathrm{E}_{6}$ ratio. This spectral wavelength rate was also connected with the humification indicators in our study; with increased humification index, the ratio $\mathrm{E}_{4} / \mathrm{E}_{6}$ decreased or stayed relatively constant. However, these changes were not significant and can be explained by the overall low decomposition degree within peat samples 


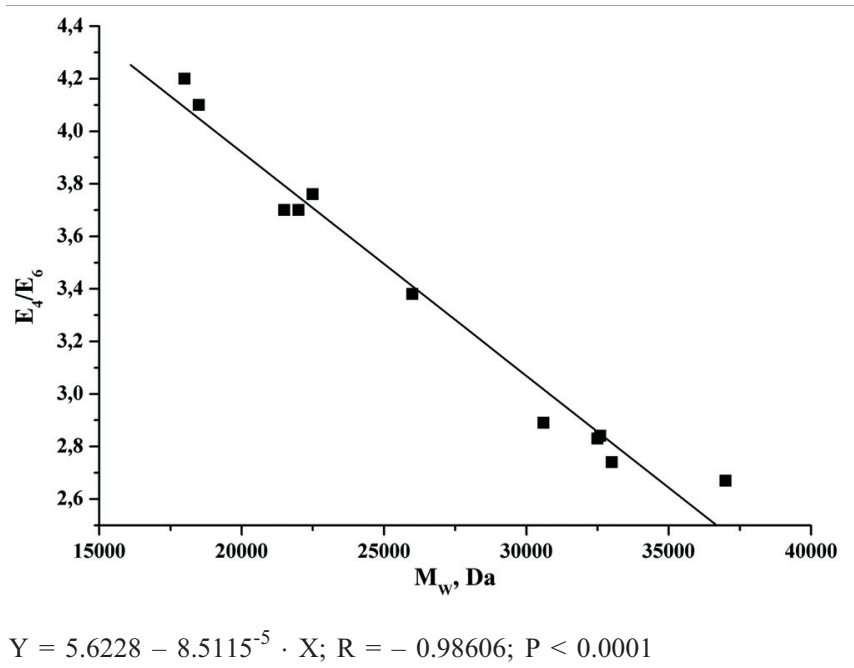

Fig. 5. Effect of molecular mass of peat HAs on the $\mathrm{E}_{4} / \mathrm{E}_{6}$. Peat sampled from Dižais Veiḳenieks, Gāgu and Kaigu peat bogs.

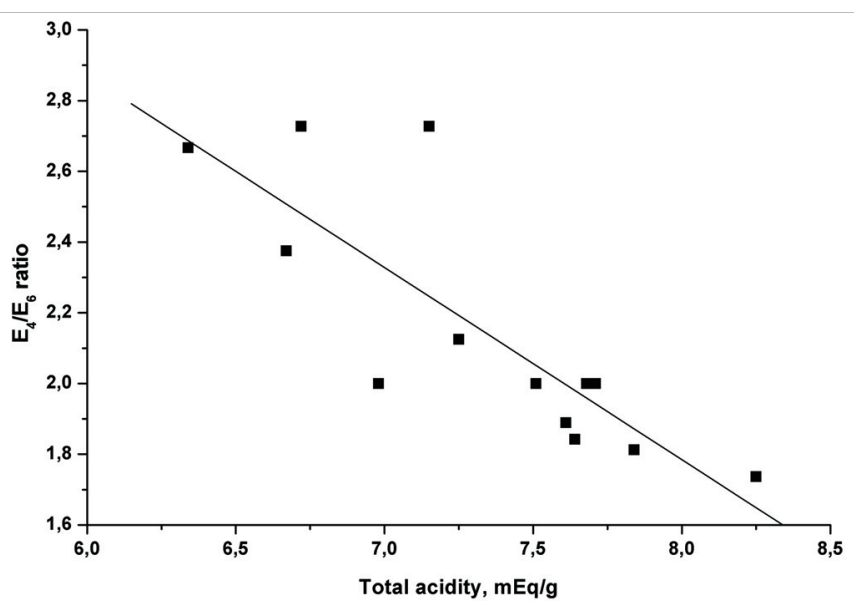

$\mathrm{Y}=6.13374-0.54365 \cdot \mathrm{X} ; \mathrm{R}=-0.82782 ; \mathrm{P}=0.002$

Fig. 6. Correlation between $\mathrm{E}_{4} / \mathrm{E}_{6}$ ratio and total acidity in Dižais Veiķenieks, Gāgu and Kaigu peat bogs.

or by dissimilar botanical composition. In some cases these parameters can be used for description of the transformation processes of organic matter within peat profiles.

In conclusion, the elemental, functional, mass-molecular and spectral characterisation of peat HAs stress the role of their origin on HS properties. The present study showed that the dominant peat mass was relatively homogeneous, while there was high variability in peat Has properties. The source of changes in peat HA properties extracted from industrially important bogs is most likely natural variability and structural changes during the humification process.

\section{REFERENCES}

Anderson, H., Hepburn, A. (1986). Variation of humic substances within peat profile. In: Peat and Water (pp. 177-194). C.H. Fuchsman (ed.). N.Y.: Academic Press.

Anonymous (2008). International Humic Substance Society. Available online at http//www.ihss.gatech.edu (verified 20 April 2008).
Alberts, J.A., Takacs, M. (2004). Total luminescence spectra of IHSS standard and reference fulvic acids, humic acids and natural organic matter: Comparison of aquatic and terrestrial source terms. Org. Geochem., 35, 243-256.

Artinger, R., Buckau, G., Geyer, S., Fritz, P., Wolf, M., Kim, J.I. (2000) Characterization of groundwater humic substances: Influence of sedimentary organic carbon. Appl. Geochem., 15, 97-116

Chen, J., Gu, B., LeBouef, E.J., Pan, H., Dai, S. (2002). Spectroscopic characterization of the structural and functional properties of natural organic matter fractions. Chemosphere, 48, 59-68.

Chen, Y., Senesi, N., Schnitzer, M. (1977). Information provided on humic substances by $\mathrm{E}_{4} / \mathrm{E}_{6}$ ratios. Soil Sci. Soc. Amer. J., 41(2), 352-358.

Chin, Y.P., Aiken, G. R. Danielsen, M. K. (1997). Binding of pyrene to aquatic and commercial humic substances: The role of molecular weight and aromacity. Environ. Sci. Technol., 31, 1630-1635.

Clymo, R.S. (1991). Peat growth. In: Quaternary Landscapes (pp. 76-112). Shane, L.C.K., Crushing E.J. (eds.). London: Belhaver Press.

Conte, P., Spaccini, R., Smejkalova, D., Nebbioso, A., Piccolo, A. (2007) Spectroscopic and conformational properties of size-fractions from a lignite humic acid. Chemosphere, 69, 1032-1039.

Corvasce, M., Zsolnay, A., D’Orazio, V., Lopez, R., Miano, T.M. (2006). Characterization of water extractable organic matter in a deep soil profile. Chemosphere, 62, 1583-1590.

Dick, D., Mangrich, A., Menezes, S., Pereira, B. (2002). Chemical and spectroscopical characterization of humic acids from two South Brazilian coals of different ranks. J. Brazil. Chem. Soc., 13(2), 177-182.

Falkowski, P., Scholes, R.J., Boyle, E., Canadell, J., Canfield, D., Elser, J., Gruber, N., Hibbard, K., Hogberg, P., Linder, S., Mackenzie, F.T., Moore, B., Pedersen, T., Rosenthal, Y., Tan, K.H. (2003). Humic matter in soil and the environment: Principles and Controversies. N.Y.: Marcel Dekker.

Francioso, O., Ciavatta, C., Montecchio, D., Tugnoli, V., Sanchez-Cortes, S., Gessa, C. (2003). Quantitative estimation of peat, brown coal and lignite humic acids using chemical parameters, ${ }^{1} \mathrm{H}-\mathrm{NMR}$ and DTA analyses. Biores. Technol., 88, 189-195.

Fong, S.S., Murtedza, M. (2007). Chemical characterization of humic substances occurring in the peats of Sarawak, Malaysia. Organ. Geochem., 38(6), 967-976.

Garnier-Sillam, E., Hariyento, S., Bourezgui, Y. (1999). Humic substances in peats. Analysis, 27(5), 405-408.

Gondar, D., Lopez, R., Fiol, S., Antelo, J.M., Arce, F. (2005). Characterization and acid-base properties of fulvic and humic acids isolated from two horizons of fan ombrotrophic peat bog. Geoderma, 126, 367-374.

Hänninen, K., Knuutinen, J., Mannila, P. (1993). Chemical characterization of peat fulvic acid fractions. Chemosphere, 27(5), 747-755.

Hertkorn, N., Permin, A., Perminova, I., Kovalevskii, D., Yudov, M., Petrosyan, V., Kettrup, A. (2002). Comparative analysis of partial structures of a peat humic and fulvic acid using one-and two-dimensional nuclear magnetic resonance spectroscopy. J. Environ. Quality, 31, 375-387.

Li, L., Huang, W., Peng, P., Sheng, G., Fu, J. (2003). Chemical and molecular heterogeneity of humic acids repetitively extracted from a peat. Soil Sci. Soc. Amer. J., 67(7), 740-746.

Lu, X.Q., Hanna, J.V., Johnson, W.D. (2000). Source indicators of humic substances: An elemental composition, solid state 13C NMR and Py-GC-MS study. Appl. Geochem., 15, 1019-1033.

Pettersson, C., Ephraim, J., Allard, B. (1994). On the composition and properties of humic substances isolated from deep groundwater and surface waters. Organ. Geochem., 21(5), 443-451.

Qiamg, T., Xiaoquan, S., Zheming, N. (1993). Comparative characteristic studies on soil and commercial humic acids. Fresenius J. Anal. Chem., 347, 330-336.

Reckhow, D., Singer, P., Malcolm, R. (1990). Chlorination of humic materials: Byproduct formation and chemical interpretations. Environ. Scie.Technol., 24(11), 1655-1664. 
Schumacher, M., Christl, I., Vogt, R.D., Bartmettler, K., Jacobsen, C., Kretzschmar, R. (2006). Chemical composition of aquatic dissolved organic matter in five boreal forest catchments sampled in spring and fall seasons. Biogeochemistry, 80, 263-275.

Senesi, N., Sakallariadou, F. (1994). Structural and functional chemical properties of marine and coastal sedimentary humic acids. Environ. Int., 20(1), 3-9.

Stevenson, F.J. (1994). Humus Chemistry: Genesis, Composition, Reactions. $2^{\text {nd }}$ edn. N.Y.: Wiley. 496 pp.

Thorn, K.A., Folan, D.W., MacCarthy, P. (1989). Characterization of the IHSS standard and reference fulvic and humic acids by solution state ${ }^{13} \mathrm{C}$ NMR spectrometry. US Geological Survey. Report 89-4196. 93 pp.

Uyguner, C.S., Hellriegel, C., Otto, W., Larive, C.K. (2004). Characterization of humic substances: Implications for trihalomethane formation. Anal. Bioanal. Chem., 378, 1579-1586.

Van Krevelen, D.W. (1950). Graphical-statistical method for the study of structure and reaction processes of coal. Fuel, 29, 269-284.

Yamaguchi, T., Hayashi, H., Yazawa, Y., Uomori, M., Yazaki, F., Bambalov, N.N. (1998). Comparison of basic characteristics of humic acids extracted from peats and other sources. Int. Peat J., 8, 87-94.

Zaccone, C., Miano, T.M., Shotyk, W. (2007). Qualitative comparison between raw peat and related humic acids in an ombrotrophic bog profile. Organ. Geochem., 38, 151-160.
Беляева Е. (2004). Изучение роли неэксклюзивних эффектов в гель-хроматографическом фракционировании гуминовых веществ [Studies on non-exclusive effects in gel chromatographic fractionation of humic substances]. Дипломная работа. МГУ, 55 с. (in Russian).

Дроздова Т. В. (1959) Спектрофотометрический метод определения количества гуминовых кислот в торфах и торфяно-болотных почвах Почвоведение, 7, 81-85 (in Russian).

Кречетова Е. (1994) Сравнительная характеристика состава и свойств гуминових кислотгорючих сланцев и почв [Comparative characterization of composition and properties of soils and humic shale]. Химия почв, 2, 57-66 (in Russian).

Ларина Н. К., Касаточкин В. И. (1966) Спектральные методы исследования гумусовых веществ [Spectral methods in research of humic substances]. Физико-химические методы исследования почв. Москва: Наука, с. 348-355 (in Russian).

Лиштван И. И., Король Н. Т. (1975) Основные свойства торфа и методы их определения [Basic properties of peat and methods for their determination]. Минск: Наука и техника, 320 с. (in Russian).

Марков В. Д., Олунин А. С., Оспенникова Л. А., Скобеева Е. И., Хорошев П. (1988) Торфяные ресурсы мира. Справочник [World peat resources] (Ред. Оленин А. С.). Москва: Недра, 383 с. (in Russian).

Орлов Д. С. (1990) Гумусовые кислоты почв и общая теория гумификации [Soil humic acids and general humification theory]. Москва: Изд-во МГУ, 325 с. (in Russian).

Received 10 June 2009

\section{HUMIFIKĀCIJAS IETEKME UZ KŪDRAS HUMUSVIELU ĪPAŠĪBĀM}

Pētījumā veikts komplekss un salīdzinošs kūdras humīnskābju (HS) raksturojums, kuras izdalītas no dažādos Latvijas purvos iegūtiem profiliem. Paraugos noteikts elementsastāvs un funkcionālo grupu saturs, kā arī analizēts karboksilgrupu daudzums un molekulmasa, bet spektrālā analīzē lietotas ultravioletās, infrasarkanās, elektronu paramagnētiskās rezonanses un fluorescences emisijas spektroskopijas metodes. Lai veiktu paraugu strukturālo analīzi, tika izmantotas kodolmagnētiskās rezonanses $\left({ }^{1} \mathrm{H}\right.$ un $\left.{ }^{13} \mathrm{C}\right)$ spektroskopijas metodes. No Latvijas purviem izdalīto HS īpašǐbas tika salīdzinātas ar HS no citiem avotiem (ūdenu, augsnes, ogles un sintētiskajām humusvielām). Galvenās kūdras humīnskābju īpašības ir atkarīgas no to izcelsmes, norādot uz humifikācijas procesu nozīmi. Humīnskābes, kuras izdalītas salīdzinoši jaunas kūdras, sastāvs ir līdzīgs augsnes humusvielām, tomēr HS ar lielāku humifikācijas pakāpi ievērojami atšķiras no augsnes un no brūnoglēm izdalītām humīnskābēm. 